\title{
China takes centre stage for liver proteome
}

\section{David Cyranoski, Changsha, China}

China is set to lead a massive research project to describe all of the proteins in the human liver - the liver proteome. The initiative is being coordinated by the Human Proteome Organisation (HUPO), an international group that is also overseeing plasma and brain proteome projects.

But parts of China's plan are controversial - in particular, a project to generate a range of different antibodies in one go.

Last month, China surprised the world of protein chemistry by pledging 200 million yuan ( $\$ 24$ million) for the threeyear pilot phase of the international liver-proteome study. Two weeks later, researchers at China's annual proteomics meeting, on 18-21 September, established a Chinese branch of HUPO and elected as its director the ambitious Fuchu $\mathrm{He}$, a systemsbiology researcher at the Beijing Institute of Radiation Medicine.

"This is a golden opportunity for China to lead an international effort," says $\mathrm{He}$, who will coordinate activities in up to 20 countries including Canada, France and the United States.

He says that China is drawn to the project because of the toll that liver diseases such as hepatitis and hepatoma take on the population. According to the World Health Organization, China has one-third of the world's carriers of hepatitis B, and each year the disease kills 280,000 people there.

The project aims to identify all of the tens, or hundreds, of thousands of proteins that are expressed in the human liver. It will also collect information about their concentrations in normal and diseased states, where they are localized within the liver, which other proteins they interact with, and whether they exist in various chemically modified forms.

The pilot phase has already begun. French scientists will coordinate sample collection, which will gather normal and diseased tissue taken during transplant surgery from African, Asian (Mongolian) and Caucasian populations. By the end of 2005, the project's planners hope to have data on some 3,000-5,000 liver proteins. By 2010 they hope to have pinned down 10,000 proteins.

One of the project's most valuable resources could be a huge collection of monoclonal antibodies that a team at the Beijing Institute of Radiation Medicine is planning to generate and make available at cost to scientists around the world.

The team, led by immunologist Qihong Sun, intends to make antibodies against 5,000 proteins by the end of 2005 , using a technique that they consider to be particularly suitable for large-scale analysis. Con-

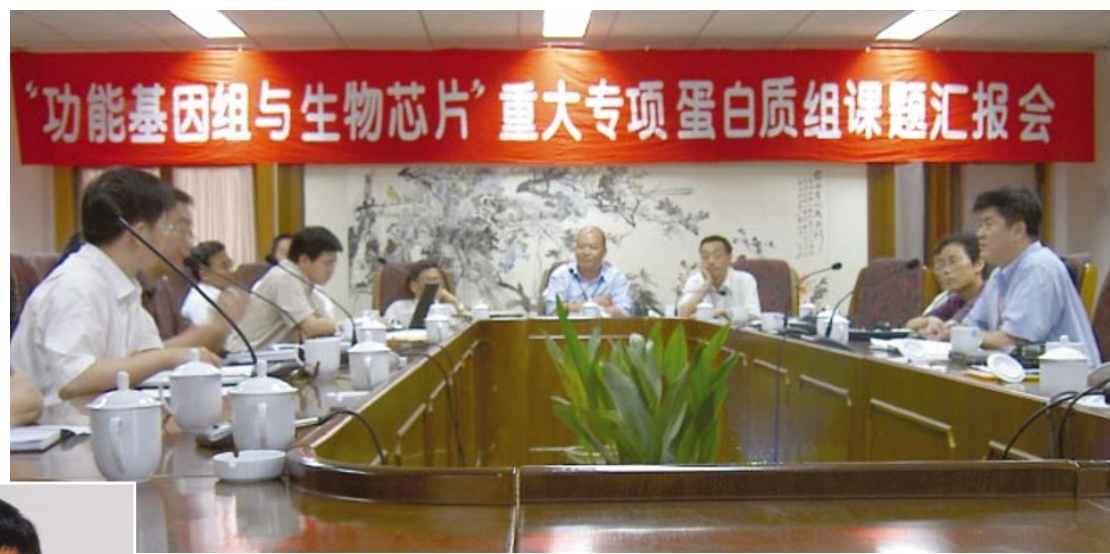

Fuchu He (left) has the task of coordinating China's project to identify liver proteins.

ventionally, antibodies are made one at a time, but Sun's team will inject several different proteins extracted from human livers into mice and then harvest the antibodies made to each of them from the mice's blood. These antibodies will be identified individually by identifying the specific protein to which each binds. "This is a fast approach, particularly for the highly abundant proteins we will be analysing first," says Sun.

But the antibody project might prove to be a diplomatic headache for HUPO, which is trying to standardize practices among the various proteome projects. "The dust has not settled yet on the choice of strategy for antibody production," says HUPO's president Samir Hanash of the University of Michigan.
Helmut Meyer of the University of Bochum, Germany, who heads HUPO's brain-proteome project, thinks that the Chinese researchers may be biting off more than they can chew. "Sometimes it's nearly impossible to identify the protein to which an antibody binds," he says. His brain-proteome project plans to start an antibody project next year using single purified or synthesized proteins to generate antibodies.

This issue will be thrashed out at HUPO's second international meeting in Montreal, Canada, next month. According to $\mathrm{He}$, this meeting will also address the issue of continued funding for the liver proteome project. The Chinese have made a tentative promise to invest a further 1.8 billion yuan to carry the project through to 2010, but he hopes that other countries will also contribute.

\section{Planck makes permanent posts}

\section{Quirin Schiermeier, Munich}

In some ways, the cure became part of the disease. Rules set up in Germany last year, intended to improve career paths for researchers, restricted scientists to a maximum of 12 years of public funding.

But young scientists who stay in Germany may need this time just to complete their $\mathrm{PhD}$, one postdoc and one contract as an independent junior researchgroup leader in a university or research institute - even though a permanent academic job such as a professorship usually requires more experience than this.

Now, in a surprise move, the Max Planck Society (MPS) will relax its strict non-tenure recruitment policy in a bid to help some of the heads of junior research groups in its $\mathbf{8 0}$ research institutes to stay in the system.

The society's rules allow only one fiveyear contract as a junior research group leader. But the MPS now plans to allow the institutes to offer its best junior research heads de facto permanent positions when their five-year contracts run out.

"We need to give young scientists more time to develop the experience and track record they require," says Herbert Jäckle, a director at the Max Planck Institute of Biophysical Chemistry in Göttingen and vice-president of the MPS. "Otherwise, most of them will be forced, against their will, to continue their careers abroad, or outside the academic system."

Jäckle says that only the potential highflyers among the society's 100 or so young group leaders will be offered extensions. The MPS likes researchers to leave when they have a strong publication list, to take up jobs at universities. "It is of course possible that some might stay forever," says Jäckle, adding that "this is a risk we're ready to accept." 